\title{
The Essential Elements Underlying Formation of Tourist Friendly Destination Concept: Analysis in Micro Level
}

\author{
Ahmad Nazrin Aris Anuar ${ }^{1,2}$, Habibah Ahmad ${ }^{2}$, Hamzah Jusoh² \& Mohd Yusof Hussain ${ }^{2}$ \\ ${ }^{1}$ Centre of Studies Park \& Amenity Management, Faculty of Architecture, Planning \& Surveying, Universiti \\ Teknologi MARA, Shah Alam, Selangor Darul Ehsan, Malaysia \\ 2 School of Social, Development and Environment, Faculty of Social Sciences and Humanities, National \\ University of Malaysia, Bangi, Selangor Darul Ehsan, Malaysia \\ Correspondence: Ahmad Nazrin Aris Anuar, Centre of Studies Park \& Amenity Management, Faculty of \\ Architecture, Planning \& Surveying, Universiti Teknologi MARA, Shah Alam, Selangor Darul Ehsan, Malaysia \\ Tel: 60-13-364-6137. E-mail: aek_2751@yahoo.com
}

Received: June 7, 2012 Accepted: June 28, 2012 Online Published: October 28, 2012

doi:10.5539/ass.v8n13p59 URL: http://dx.doi.org/10.5539/ass.v8n13p59

The research is financed by Ministry of Higher Education Malaysia, Universiti Teknologi MARA and National University of Malaysia.

\begin{abstract}
Tourist friendly destination is a concept that provides tourists with satisfaction through connection and maximum use of space, activities, and products without any interference or problems, beginning from the home all the way to the desired tourism destination. It is viewed as a customer-oriented concept where the tourist is the customer. However, studies that of such initiatives are quite limited and sector based, thus leaving a gap of knowledge and misunderstanding about a usage of tourist friendly destination. Accordingly, this study is a concept paper that aims to identify elements within the tourism system approach through the aspects of space, activities, and products which form the underlying formation of tourist friendly destination concept. The findings of this study have identified five elements from the aspect of space, four elements from the aspect of activities, and five elements from the aspect of products. Therefore, it is hoped that this study can help stakeholders to create tourist friendly destination concept using the elements in the tourism system approach, based on tourists' wants and needs.
\end{abstract}

Keywords: elements, micro level, tourism destination, tourism system, tourist friendly destination concept

\section{Introduction}

Tourist friendly destination are created from a combination aspect of space, activities, and products within the tourism system approach (Anuar et al., 2012a). In this combination, each aspect plays its own role and is subsequently used at tourist friendly destination concept with the aim of making tourists feel happy and free from any complications or problems. On a macro level, the aspect of space functions to fulfil the primary motivations behind tourists' desire to spend time at tourism destination (Anuar et al., 2012a). Even Vukonic (1997) stated that the more space would be used, it will be increased a satisfaction and attendance of tourist to the tourism destination. In addition, Hudson (1998) stated that a space, which is equipped with required facilities and infrastructures needed by tourists in tourism destination, especially in tourist friendly destination (customer-oriented branding). In fact, Hudson (1998) also pointed out that facilities and services, which satisfy the tourist need and want such as food and accommodation, are vital in extending a stay of the tourist in tourism destination. It shows that a space, which is equipped with an infrastructure, facilities, accommodation, attraction and others, is essential to ensure a tourist friendly destination concept fulfills the supply and demand of tourist (Anuar et al., 2012b). What are the elements from the aspect of space that form the foundation of tourist friendly destination concept on a micro level?

On a macro level, the aspect of activity functions as the pulse of tourism products (Anuar et al., 2012a). This is due to the fact that each activity that is carried out will influence the effectiveness of a destination's appeal, especially tourist friendly destination. Therefore, relevant parties are expected to create competitive activities 
that provide tourists with memorable experiences (Anuar et al., 2012c). What exactly are the elements from the aspect of activities that form the foundation of tourist friendly destination concept on a micro level?

Many studies have been carried out at a macro level by tourism scholars, most of whom view products as a tourism destination (McIntosh \& Goeldner, 1990; Kozak, 2002; Yoon \& Uysal, 2005). Among the identified products at tourism destination are natural elements (scenery, beaches, mountains, historical places, or buildings etc.). On the other hand, man-made structures consist of lodgings, transportation, infrastructure, and so forth (Van Raaij, 1986; Swarbrooke, 1995; Hudson, 1998). What are the elements from the aspect of product that form the foundation of tourist friendly destination concept on a micro level?

Although studies on tourist friendly destination concept are limited due to lack of research in the form of literature, theories, concepts, frameworks, and indicators which has left a wide gap in knowledge of this area, a preliminary study such as this one is necessary as an introduction and exposure to the concept of tourist friendly destination. In line with this, the objective of this study is to identify elements within the tourism system approach through the aspects of space, activities, and products which form the underlying formation of tourist friendly destination concept.

\section{The Elements Underlying Formation of Tourist Friendly Destination Concept}

\subsection{The Elements in the Aspect of Space Underlying Formation of Tourist Friendly Destination Concept}

In the context of tourist friendly destination concept, space plays a significant role in fulfilling tourist demands (Anuar et al., 2012a). This becomes clear through Hitrec's (1995) definition of space in which the destination as an attraction with complete facilities such as space to accommodate tourists' needs and sufficient space to fulfil primary motivations encourages tourists to spend time in the area and view the space as a holiday spot or tourist resort (Kaiser \& Helber, 1978). Ritchie \& Crouch (2003) identify five elements that are used to create a competitive tourism destination, namely infrastructure and superstructure, location, security, cost and value and accessibility. A successful tourism destination is not only influenced by elements of activities or products which are considered to have primary effects. Rather, the aspect of space also provides secondary effects which should be implemented by planners as relevant parties (Ritchie \& Crouch, 2003). The five elements are as follows:

\subsubsection{Infrastructure and Superstructure}

According to Ritchie \& Crouch (2003), infrastructure and superstructure constitute the most important element in determining the success of a tourism destination. This element is typically implemented by relevant parties aside from the private sector such as the government to develop tourism destination (Anuar et al., 2012c). Infrastructure can be defined as the basic structure of an organization, system, facility, and basic service (Kamus Dewan, 2010). Accordingly, infrastructure can be divided into two categories: general infrastructure and basic service infrastructure (Ritchie \& Crouch, 2003). Ritchie \& Crouch (2003) further describe general infrastructure as encompassing facilities, systems and services such as transportation systems (roads, highways, airports, railway systems and others), public safety (police, firemen), water supplies and sources (for industrial or individual use), electrical supplies (power stations), sewerage and drainage (sewage pools and treatment, ditch systems, rubbish collection systems and flood control works), telecommunications systems, parcel and mail delivery systems, medical systems (hospitals, clinic), monetary systems (banks, union credits), administrative systems (legal system, government offices), education systems (universities, schools) and more.

Meanwhile, basic service infrastructure may refer to retailing and shopping facilities, petrol stations, restaurants, food stalls, car workshops, pharmacies, bookstores, laundry shops, and so forth (Ritchie \& Crouch, 2003). In essence, it is considered as a support or secondary to general infrastructure. Ritchie \& Crouch (2003) also explain that basic service infrastructure is usually funded by the private sector while general infrastructure is funded by the government through tax resources. Emphasis is placed on the quality of an infrastructure. For example, a tourism destination becomes competitive when its transportation system is deemed to be of high quality, efficient, reliable, clean, and punctual in taking and sending tourists (passengers) to the desired tourism destination. Therefore, every tourism destination should ensure that their infrastructure is friendly to the tourists. Furthermore, Ritchie \& Crouch (2003) state that relevant parties such as planners should take into account good designs and planning to ensure that all infrastructure caters to tourists. This includes open spaces, corridors, doors, signboards, map locations in every corner, ticket machines to facilitate tourists and many more. This is because high quality and friendly infrastructure is the foundation of tourist friendly destination concept. In tourist friendly destination concept, the following attributes are used via infrastructural elements:

- Tourists' perception of the sufficiency of infrastructural components to fulfil their requests.

- Quality of transportation system (roads) 
- Quality of transportation system (airports)

- Quality of transportation system (ferries, boats and so forth)

-Quality of telecommunications facilities

- Quality of electricity system, water, sewerage system and so forth

In terms of superstructure elements, Richie \& Crouch (2003) define superstructure as a building or facility that is meant to fulfil the requests or interests of tourists. On the other hand, Kamus Dewan (2010) defines superstructure as a structure built on top of the main section of a building. In addition, superstructure elements consist of transportation and accommodation, food services and several main places of attraction. Superstructure elements can be divided into three categories which are enhancement of element functions, building elements and enhancement of normal and natural elements. Superstructure elements in element functions include hotels, restaurants, airports, theme parks, cruise ship ports, convention centres and interpretation centres (Ritchie \& Crouch, 2003). Meanwhile, infrastructural elements in the enhancement of building elements include museums, zoos, skyscrapers, stadiums, and commercial centres (Ritchie \& Crouch, 2003). In terms of the enhancement of normal and natural elements, examples of infrastructural elements are worship centres, history centres, universities, disaster areas, unique architecture and so on (Ritchie \& Crouch, 2003). The more buildings or facilities are built, the more tourists will come to visit the destination.

Most of the buildings constructed are very unique and have their own appeal. They may have been built specially to attract tourists or were built much earlier but now serve as tourist attractions such as the Eiffel Tower in France, the Leaning Tower of Pisa in Italy, the Statue of Liberty in New York and so on (Ritchie \& Crouch, 2003). Aside from buildings, there are also superstructures that are considered complete destinations such as Las Vegas, Disneyland, and Disney World in California, Florida and other places (Ritchie \& Crouch, 2003). The appeal of these superstructure elements can be likened to a magnetic field that is able to attract the attention of tourists. In order to do this, the design of such elements must be geared towards the concept of a tourist friendly destination. In tourist friendly destination concept, the following attributes are used:

- Tourists enjoy the appeal of the architecture

- Tourists are given priority for various types of accommodation

- Competent and quality level of maintenance

- Number of attractions within the tourism destination

\subsubsection{Location}

The element of location plays a crucial role in attracting tourists to a certain destination, and has a large impact on the tourism industry as a whole. Location can be defined as a place or position (Kamus Dewan, 2010). Though the physical characteristics of a location cannot be changed (with the exception of the passing of millions of years during which change inevitably happens), the location of tourist markets can change quickly (Ritchie \& Crouch, 2003). In the case of the Asian region, there is a rapidly flourishing market in which an abundance of wealth from neighbouring countries expands tourism so as to create competition between tourism destination in terms of location. For example, the success of countries like Japan, South Korea, Taiwan, Singapore, and Hong Kong has brought the tourist market over to China, Malaysia, Thailand, and Indonesia (Ritchie \& Crouch, 2003). Moreover, the element of space should always be considered in a tourism destination in relation to its geographical conditions, estimated distance and whether the space used is large or small. At times, the distance between the locations of tourism destination also affects tourist demands.

Consequently, the element of location is considered subjective since it is influenced by unchangeable physical characteristics. This is why tourist friendly destination concept should emphasize the element of location so that each facility, service, and attraction spot is suitable and friendly to the tourists. In tourist friendly destination concept, the following attributes are used:

- Tourists' perception of whether the tourism destination is nearby or isolated

- Tourists' perception of isolated destinations differs from individual and market estimations

- Tourists are accepting in terms of the distance of the tourism destination

- Tourists' perception of the obstacles encountered on the way to the tourism destination

- Tourists' perception of the difficulties, facilities and services at the tourism destination 


\subsubsection{Safety and Security}

The element of safety is often highlighted by tourists as it influences the success of a tourism destination. If there are many safety cases involving tourists, the destination would see a drop in the number of tourists. Safety can be defined as prosperity and peace (Kamus Dewan, 2010). Safety is not limited to basic needs and a disease-free environment, but also encompasses safety from violence and natural disasters. Most authorities at tourism destination do not take into account the issue of crimes which tourists often experience. This kind of situation could expose a destination to widespread criminal problems due to a lack of reliable legal enforcers (Holcomb \& Pizam, 2006). This serves as a warning to us that the element of safety at tourism destination is now under threat when it is actually an important indicator in preserving the quality of life for tourists (Anuar et al., 2011). Many criminal cases of murder, snatch thefts, kidnapping, rape, and burglaries involve both local and international tourists.

Increasing crime rates can cause fear or anxiety to spread among tourists. These feelings may not just occur in people who have been victims of such crimes, but also people who have never been victims and have only secondary knowledge of such incidents. Floyd et al. (2003) lists four risk factors that can damage the tourism industry at a certain destination: war and unstable politics, health, crime and violence. A combination of these factors is enough to influence a tourist's intention to visit a certain destination aside from his or her own experiences and motivations. Aside from this, Poon \& Adam (2000) state that safety is an important factor that all tourists should focus on. This point is supported by Hall \& Sullivan (1996) who define safety as a significant deciding factor in selecting a tourism destination besides its appeal. Many tourists have fallen victim to the brutality of crimes. To illustrate, there was once a case of a German tourist who was murdered in Miami, Florida as well as another case of an Englishman who was murdered near Tallahassee, Florida. Following both cases, the number of tourists to Florida decreased and the state's image as a safe tourism destination was damaged (Holcomb \& Pizam, 2006). Accordingly, it can be said that safety needs is the main factor in choosing a holiday destination as it contributes to the success of a tourism destination.

Previous researchers have stated that tourists have plenty of reasons to fear crime. In order to reduce their fears, the agencies responsible such as the police and legal institutions should play their role in reducing crimes and enhancing the safety of tourists at tourism destination (Anuar et al., 2012). In tourist friendly destination concept, the following attributes are used:

- Tourists' perception of tourists' worries and discomfort

- Tourists' perception of personal safety

- Tourists' perception of the number of authorities present at holiday destination

\subsubsection{Value and Cost}

While the element of value and cost is too sensitive and subjective to be explained, it is still an important element in forming of tourist friendly destination concept. This is because value and cost at such destinations are closely related to item and service costs (transportation cost, accommodation cost, currency exchange rate, food and beverage cost, entertainment and activity cost) and the value rate of items and services used efficiently by tourists (Ritchie \& Crouch, 2003). However, the costs and values charged for tourists are too subjective as they are influenced by local, national and global socioeconomic conditions. Value can be defined as the price charged for tourists to acquire a certain item, while cost can be defined as the expense paid to produce a certain item or service (Ritchie \& Crouch, 2003). According to Ritchie \& Crouch (2003), costs at tourism destination are determined by three factors which are transportation costs, foreign exchange rate and product and service costs. All three factors are controlled by macro surroundings (international item exchange, inflation rate, tax rate) as well as micro surroundings (competition, productivity, cost of suppliers, labour rate) (Ritchie \& Crouch, 2003).

Tourism destination that offer lower or more suitable values and costs generally receive more tourists. However, lower values and costs should not be made an excuse for low productivity, especially in the service sector. The link between value, cost, quality, reputation and image plays a role in tourism destination, especially in tourist friendly destination concept. Thus, the following attributes can be used in tourist friendly destination concept:

- Tourists' perception of level of values and costs of products and services

- Tourists' reaction towards values and costs spent

- Tourists' perception of values and costs at other tourism destination

\subsubsection{Accessibility}

The element of accessibility determines whether a tourism destination is easy to reach or not. It also influences 
the aspect of space during the formation of tourist friendly destination concept. This is because accessibility connects a tourist's place of origin to the desired of tourism destination whether it is by land, sea or air. The accessibility modes typically used by tourists are air transportation, land transportation and sea transportation (Anuar et al., 2012b). This element is influenced by macro and micro perspectives. From a macro perspective, it is influenced by widespread economic factors as well as political and social conditions (Ritchie \& Crouch, 2003). For example, the enforcement of regulations that must be adhered to in the flight industry, entering a country with a visa and permit, path connections, hubs, landing slots, airport capacities and competition between airplane companies are elements that impact and influence accessibility.

On the other hand, a micro perspective is more concerned with accessibility at a tourism destination, for instance accessibility to beaches, national parks, mountains, lakes and so forth. This perspective is governed by the demands of the tourism industry (relevant parties) that are in turn influenced by economic conditions and the social demands of tourists. At a tourist friendly destination concept, accessibility plays its own role through a macro and micro approach to enable tourists to enjoy facilities, products and activities easily. Therefore, the following attributes can be used in tourist friendly destination concept:

- Tourists' perception of convenience to access at tourism destination

- Tourists' perception of accessibility via sea transportation

- Tourists' perception of accessibility via land transportation

- Tourists' perception of accessibility via air transportation

\subsection{The Elements in the Aspect of Activities Underlying Formation of Tourist Friendly Destination Concept}

Activity plays an important role in creating tourist friendly destination concept (Anuar et al., 2012a). Gunn (1994) definition of tourism also mentions the role of activities during a holiday. Thus, the role and element of activity at such destinations should be made clear in order to take into account the suitability of the users who will be doing the activity aside from making the destination a tourist friendly one. To ensure that the activities there fulfil tourist demands, activities should be considered and examined in-depth. In a study by Ramirez et al. (2006), ten indicators are given that form activity-friendly communities. The indicators are use of land surroundings, accessibility, surrounding transportation, aesthetics, travel patterns, use of land economics, economics of transportation, policy institutions and organizations and promotion. These indicators were identified for the purpose of helping relevant parties such as policymakers and community members design an activity-friendly community. Besides research by Ramirez et al., a study was also conducted by Ritchie \& Crouch (2003) which described four activity elements needed in each tourism destination. All of these elements are necessary to design activities that are tourist friendly detination and can influence tourists' motivation to choose their destination. The elements are as listed below:

\subsubsection{Culture and History}

Culture and history are considered the most important activity dimension and are influences by time and history. According to Ritchie \& Crouch (2003), this element provides maximum satisfaction as it possesses a unique identity wherein it supplies an experience that goes beyond daily activities. In a study by Ritchie \& Zins (1978), 12 subcomponents are listed under the aspect of activity which influences culture and history. These components include handicraft products, the languages spoken, traditions practiced, ways of serving food, identified arts and music, history, work methods or technology usage, architecture, religions followed, education, manner of dressing and leisure activities that influence community practices.

A tourism destination that can offer its tourists unique activities that provide new experiences adds value to its competition rate, particularly through the formation of tourist friendly destination concept. The following attributes are used in tourist friendly destination concept:

- Wealth of culture

- Culture has been studied

- Deemed exotic

- Tourists are familiar with the culture

- The culture is deemed unique

- Sophistication of the culture

- Tourists enjoy the food 
- Tourists enjoy the local music

- Enjoy the architecture

- Tourists accept/reject the diversity of religions

- Tourists accept/reject the diversity of races

- Manner of dressing that creates a cultural identity

- Existence of traditions

-Existence of work practices

- Existence of leisure activities

- Existence of a unique community

\subsubsection{Special Events}

The element of special events was created so that activities conducted at tourist friendly destination are always remembered afterwards by tourists. Special events refer to a variety of activities that bring happiness and involve the participation of tourists and local residents (Ritchie \& Crouch, 2003). Furthermore, Ritchie \& Crouch (2003) note that the spectrum of this element range from events at a local level to a global level such as the Olympic Games, Commonwealth Games, Asian Games and World Cup. Although special events are meant to increase the flow of tourists, they also emphasize the participation of local residents. There are two types of special events: hallmark events and mega events (Ritchie \& Crouch, 2003). Hallmark events can be defined as events that pay little attention to size and economic effect. These events are usually unique in nature and have an effect on tourists and the tourism destination. Examples include the Quebec Winter Carnival (Canada) and the Wimbledon Tennis Championship (England) (Ritchie \& Crouch, 2003). Meanwhile, mega events refer to events that prioritize size and economic effect rather than status and importance (Ritchie \& Crouch, 2003). These include the Los Angeles Bocentennial (USA) and the 500th Anniversary of The Discovery of America (Ritchie \& Crouch, 2003).

Getz (1997) outlined the factors that must exist in such events to attract more tourists to come to the area and participate. Specifically, each event must have a variety of goals, a festive spirit, fulfil basic needs and be unique, of good quality, authentic, traditional, flexible, hospitable, outstanding, symbolic, capable and comfortable. The relevant parties should adhere to all these factors to further develop activities at their respective tourism destination. Additionally, Getz (1997) provided a typology and identified seven categories of special events. The categories are not distinguished in terms of economic effect, size, importance and so forth compared to research by Ritchie \& Crouch (2003). Instead, the categories are cultural festivals, arts and entertainment, business and trade, sports competitions, education and science, recreation, politics and individual events (Getz, 1997). In shaping a tourist friendly destination concept, the relevant parties should think of special events in relation to activities so that tourists may gain unique experiences. Accordingly, the following attributes are used in tourist friendly destination concept:

- Interested in/Capable of participating in events while on holiday

- Tourists' interest in participating in unique events

- Desire to see mega events

- Interest in seeing famous/renowned events at an international level

- Interested in seeing events that reflect the nature of the destination

- Extent to which tourists reconcile events with the destination. Example: Boston Marathon

\subsubsection{Entertainment}

Entertainment can be perceived as an activity element that is necessary in both tourism destination and tourist friendly destination. Entertainment acts as a strength and main attraction aside from completing other elements such as special events, culture and history. This is detailed by Ritchie \& Crouch (2003) who state that activities and special events are considered are necessary traditional components for tourism destination, though entertainment elements are more inclined to the local traits of a destination such as Las Vegas (gambling), London (theatre) and New York (Broadway shows). This is due to the fact that prior to the advent of technology-based entertainment such as television, people created their own entertainment as a hobby.

In addition, Europe and Asia are famed for their wealth of culture and history which means that most forms of entertainment lean more to culture. This is why cultural holidays are more famous in both continents. Therefore, 
the relevant parties should use entertainment elements as stepping stones to form dynamic tourist friendly destination concept. In doing so, the following attributes are used:

- Tourists are inclined towards active or passive entertainment

- Tourists are interested in expanding the range of their life experiences

- Tourists accept/enjoy various types of entertainment

- Tourists are interested in acquiring a hands-on entertainment experience

- Interested in seeing personalities up close

- Variety of entertainment provided

- Size and uniqueness of entertainment provided

- Suitability of entertainment provided

\subsubsection{Mix Activities}

Mix activities constitute a primary element that stimulates tourists' physical and emotional traits, ultimately capturing their interest to visit a certain destination. It is a critical element as without it, a tourism destination would deteriorate or attract few tourists. This is because the reason tourists visit tourism destination is to take part in the activities prepared there which leave them with unforgettable memories. In producing tourist friendly destination concept, the relevant parties should create activities that leave a deep impact in terms of experience and memory (Anuar et al., 2012c). Combined activities can be seen as a combination of physiography, climate, culture and history coupled with creativity and initiative on the part of relevant parties. According to Ritchie \& Crouch (2003), the importance of activities as a dimension of a tourism destination's appeal is constantly evolving as tourists seek new experiences. In line with this, the relevant parties should brainstorm activities needed by tourists and take advantage of available resources and historical values. For example, a destination rooted in the concept of nature would have activities based on natural conditions and the surrounding geography. Relevant parties would also utilize the benefits and advantages of nature without alienating the values of the local community (Ritchie \& Crouch, 2003).

From the perspective of the destination, activities can be categorized according to many ways and characteristics. There are two popular characteristics that describe the nature of activities at tourism destination. The first characteristic is that an activity should be consistent with the nature and topography of the place that tourists want to do it. It should also be consistent with local community values, adhere to local rules, provide activities that complement each other so that tourists can make the most out of them are suitable for all seasons, viable and suited to different demographics, especially income. Finally, every activity should have a unique design that fits the requirements of the destination (Ritchie \& Crouch, 2003). The second characteristic is that an activity should consist of recreation, education, high cost, low cost, sophistication, activeness, passiveness, off the beaten track and vice versa, indoor or outdoor activities, difficult or easy adventures, relaxation, easy accessibility or vice versa, family-oriented activities or vice versa or adult-oriented activities (Ritchie \& Crouch, 2003). Consequently, the following attributes are used via this element in tourist friendly destination concept:

- Requirements of the prepared activities

- Priority of desired individual activities

- Quality of facilities to carry out activities

- Enjoys group activities or individual activities

- Awareness of value and cost of activities offered

- Uniqueness of activities offered

- Range of activities offered

\subsection{The Elements in the Aspect of Products Underlying Formation of Tourist Friendly Destination Concept}

A product is seen as a necessary aspect of creating a tourism destination as it fulfils tourist demands (Anuar et al., 2012a). There are many existing studies that explain the relation between products and tourism. In a study carried out by Bramwell (1998), it is noted that four elements influence products which are primary products in the activity area, primary products for leisure, secondary products and additional products. This study used the product model from Jansen-Verbeke's research. In the study, the researcher used these elements to identify tourist satisfaction towards products within the city tourism area. The findings helped to improve product planning and development in the town's development area (Bramwell, 1998). Furthermore, Murphy et al. (2000) 
elaborated that product elements can be divided into two subcomponents, namely destination surroundings and service infrastructure. In terms of destination surroundings, the elements used are natural environment and political, technological, economic, cultural and social factors. Meanwhile, the second subcomponent refers to service infrastructure and the elements used are shopping, recreation and attraction, food, tourism, transportation and lodging services. Through this study, the researcher discovered that both product subcomponents are significant in relation to tourists' perceptions.

Smith (1994) proposed a model closely related to the product which contained five elements: physical characteristics, service, hospitality, freedom of choice and involvement in creating products at tourism destination. In this study, Smith (1994) described tourism as an industry with qualities similar to generic products and the manufacturing process. Many tourism scholars agree with this assessment, stating that tourism products are the foundation of a tourist's experiences. The product model was later utilized by Xu (2010). In his study, he used the elements of physical characteristics, service, hospitality, freedom of choice and involvement in observing tourism products in other tourism sectors including theme parks, resorts, restaurants and natural environments $(\mathrm{Xu}, 2010)$. In accordance, the following product elements are used in tourist friendly destination concept:

\subsubsection{Physical Plant}

Physical characteristics form the core of tourism products and consist of natural resources such as waterfalls, wildlife or resorts (Smith, 1994). They also encompass fixed assets such as hotels, buildings, transportation and natural properties such as the weather, water quality, congestion and condition of a tourist infrastructure. This element influences tourists' experiences, and the relevant parties should think of a suitable and comfortable design to achieve the goal of tourism. The quality of physical characteristics can be evaluated through the design which informs tourists' experiences, preserves nature and facilitates tourists with a diverse range of physical capabilities and boundaries (Smith, 1994).

The element of physical characteristics is quite similar to a study by Ritchie \& Crouch (2003) which names it as the element of physiography and climate. The latter involves the landscape, scenery and climate of a tourism destination. It also involves activities in a natural setting which gives tourists enjoyment (Ritchie \& Crouch, 2003). For example, Newsome et al. (2000) identifies four subcategories of activities that involve physiography: nature-based tourism, adventure tourism, wildlife-based tourism and eco-tourism. There are even tourism destination that use weather as their image, for instance islands that use the 3'S image. According to Ritchie \& Crouch (2003), physiography and weather encompass all natural aspects of a destination's landscape and climate to ensure that tourists' needs are met. Thus, the relevant parties should take advantage of physical characteristics when building a tourist friendly destination. The following attributes are used in tourist friendly destination concept:

- Comfort

- Aesthetics

- Diversity of terrain

- Scenery

- Perception of level of suitable developments

- Perception of cleanliness and lack of damage to nature

- Destination change rate based on passing of time.

\subsubsection{Service}

The element of service is seen as a continuation of physical characteristics since service is needed to add more physicality for the use of tourists. According to Smith (1994), service can be defined as the performance of specific tasks to meet tourists' requirements. Alternatively, it can be defined as work done for the welfare (needs and interests) of many people (Kamus Dewan, 2010). For example, a hotel requires management services, front desk operations, maintenance, housekeeping, food and beverage services and others to ensure that the hotel functions properly (Smith, 1994). Moreover, the quality of a service can be measured through the performance and knowledge of the employees carrying out the service. This is because the quality of a service can impact a tourist's experience.

Tourists buy experiences that are taken from their interactions, behaviour and emotions towards their tourism destination. Efforts to increase service quality have taken into account tourists' experiences to measure their satisfaction. It should always be a priority in tourist friendly destination concept. Accordingly, the following 
attributes are used in tourist friendly destination concept:

- Tourists are satisfied with the services available

- Tourists' perception of weaknesses within the services

- Tourists' opinions on the best way to overcome weaknesses within the services

- Tourists' opinions on the best way to deliver quality service

- Tourists' perception on productivity in service delivery

\subsubsection{Hospitality}

Hospitality is an expression or feeling used by a local community to greet the arrival of tourists (Smith, 1994). According to Kamus Dewan (2010), hospitality can also be defined as friendly treatment of visitors. Smith (1994) also explains that it is difficult to measure hospital practically. Merely acquiring quality service is not enough; a touch of hospitality is needed to complete the service. If service is considered a "technically competent performance of a task," then hospitality is considered the attitude or style with which the task is executed (Smith, 1994). For instance, front desk operations at a hotel are considered a service that caters to clients of the hotel. When combined with hospitality or service with a smile, willingness to help and positive reactions to clients, the service is considered to have quality and effectiveness as well as hospitality.

In addition, hospitality influences tourism destination. Many of these destinations describe themselves as friendly destinations. Yet are they truly friendly? Ritchie \& Crouch (2003) state that in order to produce a competitive tourism destination, the elements of friendliness and hospitality must be combined so that tourists feel appreciated by the local community. This is because quality service, friendliness and hospitality can leave a lasting impression in tourists' minds. Therefore, it should be made an important agenda by the relevant parties in creating a tourist friendly destination concept. The following attributes are used in tourist friendly destination concept:

- Tourists' perception of the hospitality shown by the local community

- Tourists' sentiments of the destination wanting them to come and visit

- Tourists' perception of information services at the tourism destination which reflects appreciation for their visit

- Tourists use information centres

- Local community's acceptance of foreign languages

- Tourists' acceptance of the local hospitality

\subsubsection{Freedom of Choice}

Freedom of choice is an element that provides tourists with the opportunity to choose products that give them unique experiences and satisfaction. This means that at destinations, especially tourist friendly destination, tourists have many options to choose from based on the suitability of tourist offers and demands. According to Smith (1994), freedom of choice differs and depends on the aim of a tourist's trip whether it is for business, family or other reasons. In line with this, every product should have variations so that tourists can choose what they want based on the experience they desire. If they do not feel freedom in choosing products, they will feel less happy and calm and vice versa (Smith, 1994). Freedom of choice also depends on a person's budget, past experiences, knowledge and holiday travel packages (Smith, 1994). He further elaborates that freedom of choice can be seen clearly in a tourist's choice to participate in recreational or tourist activities, choose the mode of transportation (air, land, sea), accommodation (hotel, resort), food (restaurant) and so forth.

Freedom of choice is not limited to choice only; it also refers to the potential to create happiness and do things spontaneously or at the last minute. For instance, the management of a tourism destination may organize a surprise or spontaneous activity for tourists, which in turn makes the tourists feel that they are in the right place at the right time. Thus, they gain experience and additional value from the activities (Smith, 1994). Accordingly, the relevant parties should give tourists the opportunity to choose for themselves the products they want, and also include this element in tourist friendly destination concept. Through this element, the following attributes are used in tourist friendly destination concept:

- Perceptions of facilities, services and experiences available based on tourists' priorities

- Tourists' perception of the product ideas and experiences offered by the tourism destination chosen

- Tourists' perception of the sufficiency and demand for the products offered 


\subsubsection{Involvement}

In the tourism industry, involvement does not just include physical participation but also focuses on leisure and business activities. Smith (1994) states that successful involvement on the tourists' part in producing tourism products occurs through a combination of accepting physical elements, freedom of choice, hospitality, service and good physical conditions (accessibility, natural surroundings and good weather). This combination promises quality and customer satisfaction towards a product. An example of involvement in the element of products is when a tourist partakes in activities that give him self-satisfaction and make him feel safe and reassured when he is with other tourists or local residents.

Furthermore, Smith (1994) asserts that the foundation of successful involvement in creating tourism products is a combination of physicality, good service, hospitality and freedom of choice. In line with this, all five elements determine the level of physical, intellectual and emotional involvement in tourism services. Therefore, the following attributes are used in tourist friendly destination concept:

- Level of tourists' involvement in the products offered

- Tourists' perception of their interest in visiting tourism destination during trips

- Tourists' perception of the reception towards the products offered

- Tourists' perception of the differences in reception towards the products offered

\section{Conclusion}

Tourist friendly destination is a concept used by relevant parties to promote tourism destination. However, there is still a dearth of research in this field due to a lack of specific studies in the form of literature, theories, concepts, frameworks and indicators in the use of tourist friendly destination. As a result, this has left a gap in knowledge and caused confusion regarding the subject. Therefore, despite being a preliminary study, this research has identified the elements that form the foundation of tourist friendly destination concept on a micro level. These elements represent aspects of space, activities and products through a tourism system approach (refer Figure 1). Though the study did not employ empirical research, the interaction between elements in the aspect of activity, space and product (tourism system) forms its basis and paves the way for more in-depth research on tourist friendly destination concept. It is hoped that this study will aid relevant parties in managing tourism destination to become tourist friendly destination that utilize the elements of activities, products and space based on the wants and needs of tourists.

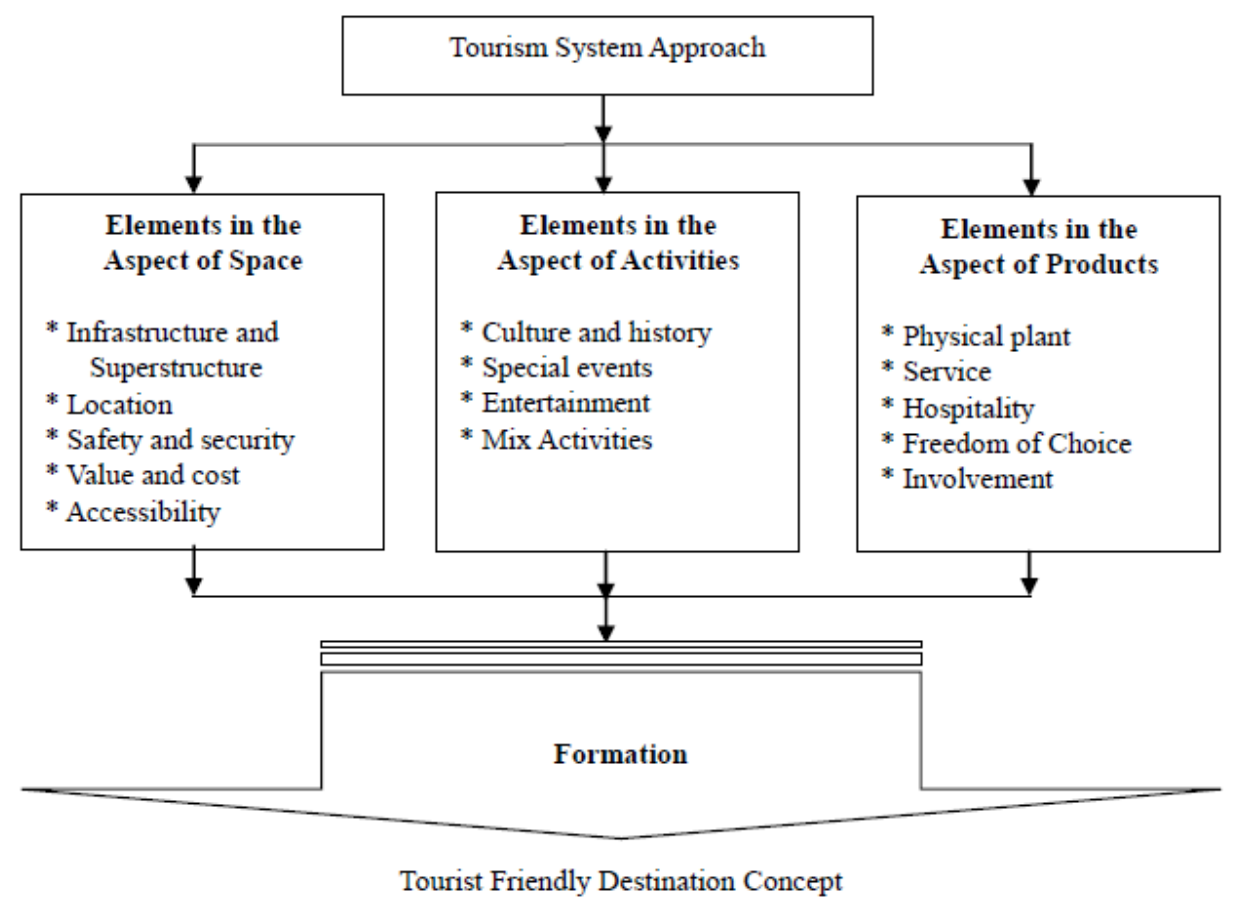

Figure 1. Conceptual framework the essential elements underlying formation of tourist friendly destination concept: analysis in micro level 


\section{References}

Anuar, A. N. A., Ahmad, H., Jusoh, H., \& Hussain, M. Y. (2012a). The roles of tourism system towards development of tourist friendly destination concept. Asian Social Science, 8(6), 146-155. http://dx.doi.org/10.5539/ass.v8n6p146

Anuar, A. N. A., Ahmad, H., Jusoh, H., \& Hussain, M. Y. (2012b). Understanding the factors influencing formation of tourist friendly destination concept. Journal of Management and Sustainability, 2(1), $106-114$. http://dx.doi.org/10.5539/jms.v2n1p106

Anuar, A. N. A., Ahmad, H., Jusoh, H., \& Hussain, M. Y. (2012c). Understanding the role of stakeholder in the formation of tourist friendly destination concept. Journal of Management and Sustainability, 2(2), 69-74. http://dx.doi.org/10.5539/jms.v2n2p69

Anuar, A. N. A., Bookhari, S. N., Aziz, N. A. (2012). The effectiveness of Safe City Programme as safety basic in tourism industry: Case Study in Putrajaya. Procedia Social and Behavioral Sciences, 42, 477-485. http://dx.doi.org/10.1016/j.sbspro.2012.04.213

Anuar, A. N. A., Jaini, N., Kamaruddin, H., \& Nasir, R. A. (2011). Effectiveness evaluation of Safe City Programme in relation to the tourism industry. Procedia Engineering, 20, 407-414. http://dx.doi.org/10.1016/j.proeng.2011.11.183

Bramwell, B. (1998). User satisfaction and product development in urban tourism. Tourism Management, 19(1), 35-47. http://dx.doi.org/10.1016/S0261-5177(97)00091-5

Dewan, K. (2010). Kamus Dewan Edisi Keempat. Kuala Lumpur: Dewan Bahasa Dan Pustaka.

Floyd, M. F., Gibson, H., Pennington, L. G., \& Thapa, B. (2003). The Effect of Risk Perceptions on Intentions to Travel in the Aftermath of September 11, 2001. In Hall, C. M., Timothy, D. J., \& Duval, D. T. (Eds.), Safety and Security in Tourism: Relationship, Management and Marketing (pp. 19-38). USA: Haworth Hospitality Press.

Getz, D. (1997). Event management and event tourism. New York: Cognizant Communication Corporation.

Gunn, C.A. (1994). Tourism Planning (3rd Ed.). London: Taylor and Francis.

Hall, C. M., \& O’Sullivan, V. (1996). Tourism, Political Instability and Social Unrest. In Pizam, A., \& Mansfield, Y. (Eds.), Tourism, Crime and International Security Issues (pp. 105-121). Chichester: John Wiley.

Hitrec, T. (1995). Tourism destination: meaning, development, concept. In Wahab, S., \& Pigram, J. J. (Eds.), Tourism, Development and growth: The challenge of sustainability (pp. 96). Great Britain: Routledge.

Holcomb, J. \& Pizam, A. (2006). Do Incidents of Theft at Tourist Destinations Have a Negative Effect on Tourists' Decisions to Travel to Affected Destinations? In Mansfeld, Y., \& Pizam, A. (Eds.), Tourism, Security and Safety: From Theory to Practice (pp. 105-124). UK: Elsevier Butterworth-Heinemann.

Hudson, B. J. (1998). Waterfalls. Resources for tourism. Annals of Tourism Research, 25(4), 958-973. http://dx.doi.org/10.1016/S0160-7383(98)00043-7

Kaiser, C., \& Helber, L. (1978) Tourism: planning and development. In Wahab, S., \& Pigram, J. J. (Eds.), Tourism, Development And Growth: The Challenge Of Sustainability (pp. 97). Great Britain: Routledge.

Kozak, M. (2002). Comparative analysis of tourist motivation by nationality and destination. Tourism Management, 23, 221-232. http://dx.doi.org/10.1016/S0261-5177(01)00090-5

McIntosh, R. W., \& Goeldner, C. R. (1990). Tourism: Principles, Practices, Philosophies. New York: Wiley.

Murphy, P., Pritchard, M. P., \& Smith, B. (2000). The destination product and its impact on traveller perceptions. Tourism Management, 21, 43-52. http://dx.doi.org/10.1016/S0261-5177(99)00080-1

Newsome, D., Moore, S. A., \& Drowling, R. K. (2002). Natural area tourism: Ecology, Impacts and Management. UK: Channel View Publications.

Poon, A., \& Adam, E. (2002). How The British Will Travel 2005. Annals of Tourism Research, 29(1), $279-281$. http://dx.doi.org/10.1016/S0160-7383(01)00051-2

Ramirez, L. K. B., Hoehner, C. M., Brownson, R. C., Cook, R., Orleans, C. T., Hollander, M., ... Wilkinson. W. (2006). Indicators of activity-friendly communities. An evidence based consensus process. American Journal of Preventive Medicine, 31(6), 1-10. http://dx.doi.org/10.1016/j.amepre.2006.07.026

Ritchie, \& Zins (1978). Culture as deterrminant of the atractiveness of a tourism region. In Ritchie, J. R. B., \& 
Crouch, G. I. (Eds.), The Competitive Destination: A Sustainable Tourism Perspective (pp. 115). UK: CABI International.

Ritchie, J. R. B., \& Crouch, G. I. (2003). The Competitive Destination: A Sustainable Tourism Perspective. UK: CABI International. http://dx.doi.org/10.1079/9780851996646.0000

Smith, S. L. J. (1994). The tourism product. Annals of Tourism Research, 21(3), 582-595. http://dx.doi.org/10.1016/0160-7383(94)90121-X

Swarbrooke, J. (1995). The Development and Management of Visitor Attractions. London:Butterworth Heinemann.

Van Raaij, W. F. (1986). Consumer research on tourism: mental and behavariol constructs. Annual of Tourism Research, 13, 1-9. http://dx.doi.org/10.1016/0160-7383(86)90054-X

Vukonic, B. (1997). Selective tourism growth: Targeted tourism destination. In Wahab, S., \& Pigrim, J. J. (Eds.), Tourism, Development And Growth: The Challenge of Sustainability (pp. 95-108). London: Routledge.

$\mathrm{Xu}$, J. B. (2010). Perception of tourism products. Tourism Management, 31, 607-610. http://dx.doi.org/10.1016/j.tourman.2009.06.011

Yoon, Y., \& Uysal, M. (2005). An examination of the effects of motivation and satisfaction on destination loyalty: a structural model. Tourism Management, 26, 45-46. http://dx.doi.org/10.1016/j.tourman.2003.08.016 